\title{
Delta-D Initiated Microorganic Digestion of Saw Dust into Organic Fertiliser - A Technically, Economically and Environmentally Feasible Solution to the Saw Dust Problem in Sri Lanka
}

\begin{abstract}
S A S Perera
Abstract: This paper, presents the results of a self financed research project, carried out by the author, to develop a method, to rapidly digest saw dust (SD) and convert it into Organic Fertilizer (OF). Since, it is well known that SD is extremely resistant to biodegradation by both aerobic and anaerobic micro organisms, the author studied the possibility of converting four types of SD, namely, Jack, Mahogany, Teak and Rubber into organic fertilizer, using a combination of Delta-D Technology and composting by aerobic micro organic activity. The research was carried out during the period August 2007 to May 2008, at No: 20, Gimpatha Road, Wattalpola, Panadura. During the first 3 months, the research carried out was on composting of pure SD with $40 \%, 45 \%$ and $50 \%$ moisture and composting of SD with similar moisture contents mixed with fish and vegetable market waste digested using Delta-D. From December 2007, the suitability of the organic fertilizer produced was tested by applying to mature plants and tender plants of fruit varieties; Papaya, Guava, Mango and Ambarella and vegetable varieties ladies fingers, egg plant, capsicum, slender gourd, bitter gourd and long beans.
\end{abstract}

Delta-D Technology $(1,2,3,4,5)$ is a patented process invented by the author to rapidly digest biomass into organic fertilizer. The novelty of the technology is that, a digestive fluid, called Delta-D, is used to rapidly break down, cellulose, carbohydrates, oils, fats, proteins, resins and other components in biomass, into simple molecules that can be absorbed by plants and other organisms, as food.

The results of the composting project clearly indicated that, samples of SD with only moisture did not undergo composting, while, samples with similar moisture contents, mixed with fish and vegetable market waste digested using Delta-D, underwent composting successfully within 2 months. Initial agricultural trials, commenced in December 2007 indicated that the organic fertilizer had positive impacts on the growth of all the species to which it was applied. The agricultural trials are continuing and the results will be published in the first quarter of 2009.

\section{Introduction}

Saw dust (SD) is a waste material produced in saw mills and wood based production plants. $\mathrm{SD}$ has become a major solid waste problem, since, at present, there is no technically, economically and environmentally viable process to use or dispose SD. As a result, SD is either haphazardly burnt without energy recovery or illegally dumped on land, in rivers, in lakes and in the ocean, where it remains undecayed for many years due to its very low biodegradability. When 1 ton of dry $\mathrm{SD}$ is burnt, it produces 1.6 tons of $\mathrm{CO}_{2}$, in addition to smoke and other particulatematter, thereby significantly polluting the atmosphere.

Some SD produced in wood based production plants is toxic due to chemical treatment of sawn timber to prevent termite and microbial attack. The standard methods of chemical treatment are, Boron Treatment and ChromeCopper-Arsenic (CCA) Treatment. CCA is extremely toxic and the saw dust produced should be incinerated in a cement or lime kiln to prevent soil and ground water contamination. CCA based SD cannot be used for composting or any other micro organic disposal system, since, Chrome, Copper and Arsenic are toxic to microorganisms.

Eng. S A S Perera, BASC(CliEng 2 fuel Science), CEng., PEng(SL), FIE(Sri Lanka), MAIChE(USA), MIChemE(UK), is a Senior Lecturer attached to the Department of Chemical and Process Engineering of the University of Moratuwa. 


\section{Survey on Production of SD and Utilisation of SD in Moratuwa and Panadura}

A Nurvey carried out by the author indicated, that the daily production of SD in Moratuwa rtiul Panaduraalone exceeds 200 tons per day. The study also revealed that attempts made by many companies to use SD as a source of fuel have not been successful, due to the high moisture content (greater than 30\%) and the high resin and ash content. When SD is ignited, after a few minutes, the flame gets extinguished, unless, a continuous stream of air is passed through the bed of SD or the bed is stirred or fluidized. This requires the supply of excess air, which dilutes the fluegas and lowers its temperature, causing unsatisfactory heat transfer and carryover of ash, as well as, unburnt SD. Moreover, since, SD has a very low density (around $200 \mathrm{~kg} / \mathrm{m}^{3}$ ), unless it is compressed into high density briquettes, its transport over long distances is uneconomical.

The survey also revealed, that, attempts made by many companies to use SD to manufacture particle boards, such as, chip boards and medium density fiber boards, have not been successful, mainly due to the high cost of imported adhesives, such as Urea Formaldehyde, Phenol Formaldehyde, Poly Urethane, Poly Styrene, Polyester and Epoxy, which makes locally manufactured products noncompetitive with imported products.

\section{The Main Reasons for the Decision to Produce Organic Fertiliser from Saw Dust}

Based on the above survey and a basic technical, economical and environmental evaluation of the various options available for the use of SD, the author was of view, that, one of the best low cost options was to convert SD into organic fertilizer by composting, since, SD has a high content of organic carbon (around $44 \%$ of C), which is much higher than most other types of solid wastes, such as, canteen/hotel/ waste (around 15\% of C), slaughter house, fish and meat market waste (around $10 \%$ of $\mathrm{C}$ ), and vegetable and fruit market waste (around $10 \%$ of C). Since, it is well known that SD is extremely resistant to biodegradation by both aerobic and anaerobic microorganisms; the author studied the possibility of converting SD into organic fertilizer, using a combination of Delta-D
Technology and aerobic micro organic composting.

\section{The Current Fertiliser Situation in Sri Lanka and its Impact on Agriculture.}

According to history, Sri Lanka was once called the granary of east asia, since, Sri Lanka was not only self sufficient in rice, but exported the surplus to foreign countries. During those times, sustainable agricultural practices were used, where farmers used organic fertilizer, self produced from agricultural and farm wastes, hence their costs of production were low. However, the present situation in Sri Lankan agriculture is that, imported chemical fertilizers are used at exorbitant costs since, Sri Lanka does not either produce chemical fertiliser or organic fertilizer of good quality in large quantities. The present (June 2008) retail market prices per metric ton (MT) of the three most demanded N, P, K, Mg fertilizers are, Urea Rs. 100,000.00, Triple Super Phosphate (TSP) Rs. 145,000.00 and Muriate of Potash (MOP) Rs. $135,000.00$, Kiesserite $\left(\mathrm{MgSO}_{4} \cdot \mathrm{H}_{2} \mathrm{O}\right)$ - Rs. $45,000.00$. The prices of these fertilizers have more than doubled during the past one year and are expected to further increase with the rising prices of crude oil. Although there is a 60 million MT deposit Rock Phosphate at Eppawela (ERP) in Sri Lanka, it cannot be used as a substitute for TSP, due to the very low solubility. If the solubility of ERP can be increased, its value will increase from Rs. 9000.00 to Rs. $145,000.00$ per MT. Although Dolomite $\left(\mathrm{MgCO}_{3} \cdot \mathrm{CaCO}_{3}\right)$ is abundant in Sri Lanka, it cannot be used as a $\mathrm{Mg}$ fertilizer, due to very low solubility. If the solubility of Dolomite can be increased, its value will increase from Rs. 1000.00 to Rs. 45,000.00 per MT.

Organic fertilizer manufactured from SD with Delta-D Technology $(1,3,4,5)$, will have high levels of $\mathrm{N}, \mathrm{P}, \mathrm{K}$ and $\mathrm{Mg}$, since $\mathrm{N}$ containing wastes are added and the solubility of locally available ERP, Dolomite and Mica are increased by Delta-D.

If SD based organic fertilizer of high N,P, $\mathrm{K}, \mathrm{Mg}$ $(1,3,4,5)$ can be produced in large quantities, their will be a ready demand for it and the local farmers will be able to get their fertilizer at a very low cost. Moreover, the Government of Sri Lanka (GOSL) gives a massive urea fertilizer subsidy (Rs. 16 billion in 2007 and 
more than Rs. 35 billion) to farmers in Sri Lanka. Soil scientists have shown that more than $75 \%$ of urea applied to soil gets washed away due to its high solubility in water, contaminating ground water, rivers, lakes and other water bodies. Manufacturing large quantities of organic fertilizer and promoting it amongst farmers will be beneficial to all stake holders, due to savings in fertilizer subsidy, non pollution of water resources, cheap fertilizer and finally cheaper agricultural commodities to the people of Sri Lanka..

\section{Some Important Characteristics of Saw Dust}

SD consists of fine particles of wood, produced as a result of, sawing of logs, sawing of timber, as well as, plaining and sanding of timber surfaces to obtain a smooth finish. Wood (6) can be divided in to two main types, Softwood (Coniferous) and Hardwood (Deciduous). The main constituents of wood are, cellulose, hemicellulose, lignin, as well as, extractives: resin acids, fatty acids, turpenoid compounds, and alcohols. All these are carbohydrates (formed by the combination of the elements $\mathrm{C}$, $\mathrm{H}$ and $\mathrm{O}$ ), synthesized by the plant for various functions.

Cellulose (6) is a polysaccharide (polymer formed by combination of sugar molecules). It is formed within a plant by natural condensation polymerization of glucose $\left(\mathrm{C}_{6} \mathrm{H}_{12} \mathrm{O}_{6}\right)$ and has the general formula $\left(\mathrm{C}_{6} \mathrm{H}_{10} \mathrm{O}_{5}\right)_{n}$, where $\mathrm{n}$ is called the degree of polymerization (DP) and is around 600-1500 for commercial wood. The polymeric linkages during cellulose synthesis are such that the chains form in an extended manner. As a consequence, cellulose molecules fit snuggled together over long segments, giving rise to powerful associative forces that are responsible for the greater strength of cellulosic materials. The properties of cellulosic material are related to DP of cellulose molecules. Long chain cellulose is known as alpha cellulose. A number of shorter chain polysaccharides, known collectively as hemicellulose, also form parts of the woody structure of a plant. Hemicelluloses are polysaccharides formed by natural condensation polymerization of five (5) different sugars, namely, hexoses: glucose, mannose, galactose and pentoses: xylose and arabinose. Hemicelluloses are categorized according to DP as, beta cellulose (DP - 15 to 90) and gamma cellulose (DP less than 15).
Lignin is a highly polymerized, amorphous material available in wood. Its principal role is to form the middle lamella, the intercellular material which cements the fibers together. The structure of lignin mainly consists of phenyl propane units linked together in three dimensions.

\section{Some Reasons for the Inability of Microbes to Breakdown (Digest) Saw Dust}

It is well documented in literature that it is extremely difficult to breakdown SD by anaerobic or aerobic microbes. Information obtained through interviews the author conducted with owners and operators of saw mills clearly indicated that many of them had tried to produce biogas by anaerobic digestion of SD while many others had tried to compost SD by burying in pits. In all these experiments, SD has not undergone any kind of digestion and had remained unchanged for years. The main reasons that could be attributed to the inertness of SD towards micro organic activity are as follows.

1. Almost all the constituents of wood are chemically stable.

2. Some extractives are toxic to micro organisms.

3. To breakdown cellulose and lignin, which are the main constituents of SD, the enzymes cellulase and lignase (7) are required and most of the naturally occuring microorganisms do not have such capabilities.

4. Mainly nitrogen and to a lesser extent phosphorous are required by microorganisms for catabolism (7) (enzyme catalysed breakup of large molecules of carbohydrate, fat and protein into smaller molecules, which produces energy), anabolism ${ }^{(7)}$ (synthesizing large macro molecules, such as, polysaccharides, proteins and nucleic acids, which requires energy) and bioenergetics(7) (storing energy produced by catabolism and releasing energy for anabolism). The C:N ratio should be $25: 1$ or more favourable towards N. Such levels of N and P are not available in SD.

\section{Fundamentals of Composting}

Composting $(8,9,10,11,12,13)$ can be defined as a process by which aerobic microorganisms 
break down organic matter and produce carluin dioxide, water, heat, and humus. Under correct conditions of nutrition and aeration, composting proceeds through the following three phases in chronological order.

1)The Mesophilic Phase - a moderatetemperature phase, which lasts for a few days.

2)The Thermophilic Phase - a hightemperature phase, which can last for several weeks.

3)The Maturation Phase - at the end of this phase the end product becomes stable.

The first phase of decomposition is carried out by mesophilic microorganisms, which rapidly break down the readily degradable compounds. The heat produced causes the compost temperature to rise rapidly. As the temperature rises above $40^{\circ} \mathrm{C}$, the mesophilic microorganisms become less active and are replaced by thermophilic (heat loving) microorganisms commencing the second phase of digestion. At temperatures of $50^{\circ} \mathrm{C}$ and above, many microorganisms that are human or plant pathogens (harmful to human and plants) are destroyed. Since temperatures above $65^{\circ} \mathrm{C}$ could kill both good and bad microbes, thereby drastically reducing the rate of decomposition, it is important to manage the temperature below this point by cooling by aeration. During the thermophilic phase, high temperatures accelerate the breakdown of proteins, fats, and complex carboydrates like cellulose and hemicellulose, the major structural molecules in plants. As the supply of these high-energy compounds becomes exhausted, the compost temperature gradually decreases and mesophilic microorganisms once again take over for the final phase of "curing" or maturation of the remaining organic matter.

\subsection{Some Microorganisms Who Play A Significant Role In Composting(8)}

\subsubsection{Bacteria}

Bacteria are the smallest and the most diversified group of living organisms which constitute $80 \%$ to $90 \%$ of the billions of microorganisms typically found in a gram of compost. Bacteria are responsible for most of the decomposition and heat generation in compost. They are also the most nutritionally diverse group of compost organisms, using a broad range of enzymes to chemically break down a variety of organic materials. Bacteria are single-celled and structured as either rodshaped bacilli, sphere-shaped cocci or spiralshaped spirilla. Many are motile, meaning that they have the ability to move under their own power. At the beginning of the composting process $\left(0-40^{\circ} \mathrm{C}\right)$, mesophilic bacteria predominate. Most of these are forms that can also be found in topsoil. As the compost heats up above $40^{\circ} \mathrm{C}$, thermophilic bacteria take over. The microbial populations during this phase are dominated by members of the genus Bacillus. The diversity of bacilli species is fairly high at temperatures from $50-55^{\circ} \mathrm{C}$ but decreases dramatically at $60^{\circ} \mathrm{C}$ or above. When conditions become unfavorable, bacilli survive by forming endospores, thick-walled spores that are highly resistant to heat, cold, dryness, or lack of food. They are ubiquitous in nature and become active whenever environmental conditions are favorable. At the highest compost temperatures, bacteria of the genus Thermus have been isolated. Composters sometimes wonder how microorganisms evolved in nature that can withstand the high temperatures found in active compost. Thermus bacteria were first found in hot springs in Yellowstone National Park and may have evolved there. Other places where thermophilic conditions exist in nature include deep sea thermal vents, manure droppings, and accumulations of decomposing vegetation that have the right conditions to heat up just as they would in a compost pile. Once the compost cools down, mesophilic bacteria again predominate. The numbers ?nd types of mesophilic microbes that recolonize compost as it matures depend on what spores and organisms are present in the compost as well as in the immediate environment. In general, the longer the curing or maturation phase, the more diverse the microbial community it supports.

\subsubsection{Actinomycetes, Fungi, Protozoa and Rotifers $(7,8,9,10,11,12,13)$}

Actinomycetes give the characteristic earthy smell to soil and resemble fungi, although they are actually filamentous bacteria. They lack nuclei, but they grow multicellular filaments like fungi. In composting they play an important role in degrading complex organics such as cellulose, lignin, chitin, and proteins. Their enzymes enable them to chemically break down tough debris such as woody steins, bark, or newspaper. Some species appear during the thermophilic phase, and others become important during the cooler 
curing phase, when only the most resistant compounds remain in the last stages of the formation of humus. Actinomycetes form long, thread-like branched filaments that look like gray spider webs stretching through compost. These filaments are most commonly seen toward the end of the composting process, in the outer 10 to 15 centimeters of the pile. Sometimes they appear as circular colonies that gradually expand in diameter.

Fungi include moulds and yeasts, and they are collectively responsible for the decomposition of many complex plant polymers in soil and compost. In compost, fungi are important because they break down tough debris, enabling bacteria to continue the decomposition process once most of the cellulose has been exhausted. They spread and grow vigorously by producing many cells and filaments, and they can attack organic residues that are too dry, acidic, or low in nitrogen for bacterial decomposition.

Most fungi are classified as saprophytes because they live on dead or dying material and obtain energy by breaking down organic matter in dead plants and animals. Fungal species are numerous during both mesophilic and thermophilic phases of composting. Most fungi live in the outer layer of compost when temperatures are high. Compost moulds are strict aerobes that grow both as unseen filaments and as gray or white fuzzy colonies on the compost surface.

Protozoa are one-celled microscopic animals. They are found in water droplets in compost but play a relatively minor role in decomposition. Protozoa obtain their food from organic matter in the same way as bacteria do but also act as secondary consumers ingesting bacteria and fungi.

Rotifers are microscopic multicellular organisms also found in films of water in the compost. They feed on organic matter and also ingest bacteria and fungi.

\section{A Brief Description of Delta-D Technology $(1,3,4)$}

By using Delta-D Technology, all types of organic waste matter can be digested within a few hours, by mixing with a digestive fluid called Delta-D. After digestion, an acidic organic slurry is obtained, which is mixed with
Eppawela Rock Phosphate, Dolomite, Mica, etc., to increase the $\mathrm{N} / \mathrm{P} / \mathrm{K} / \mathrm{Mg}$ and other micronutrient levels, while neutralizing Delta$\mathrm{D}$, in the organic fertilizer produced. This product is sieved and the powder is packed and sold as organic fertilizer. Undigested large particles of organic matter remaining on the sieve are recycled back to the process and the polythene, plastics, metal and glass particles that remain on the sieve are cleaned and sold to recycling companies.

The main advantage of Delta-D Technology, is that, digestion can be done within a few hours, whereas, traditional processes, such as, composting and biogas generation require more than 3 months to digest organic waste, due to which, large quantities of Urban Solid Waste have to be stockpiled for several months, requiring large extents of land. Another advantage of this process, is that, it produces pathogen free, odorless, organic fertilizer richer in $\mathrm{N}, \mathrm{P}, \mathrm{K}, \mathrm{Mg}$ and other nutrients than traditional compost. The process does not produce leachate which is a highly polluting liquid with high BOD and COD values, commonly produced in open dumps, landfills and composting plants. Another unique feature of the process is the value addition to local, naturally occurring minerals, such as, Eppawela Rock Phosphate, Dolomite, Mica, etc. to produce a nutrient rich organic fertilizer.

The composition of the digestive fluid has to be varied according to the composition of the organic waste that has to be decomposed, as well as, the rate at which the organic matter is to be digested. The composition of the digestive fluid required to digest saw dust, straw or paddy husk will be different to that required to digest fruit and vegetable waste which in turn will be different to that required to digest fish and meat waste. Hence the composition of the digestive fluid will be decided on the basis of the waste to be digested at any given time.

The composition of the digestive fluid has to be varied according to the level of disinfection required in the organic fertilizer, as well. For example, if the organic waste consists of highly infectious material, such as, rotten fish, meat, sewage, or clinical waste produced in hospitals, etc., the composition of the digestive fluid can be adjusted to automatically increase the temperature of the digestive mix to $100^{\circ} \mathrm{C}$ or more, so that all harmful pathogenic micro- 
organism are automatically destroyed. After Ihe digestion is complete, a thick, dark brownish, acidic slurry, is produced which can be neutralized using a mineral powder mix. The composition of the mineral powder will depend on the required composition of the final product, which will be an organic fertilizer containing water soluble $\mathrm{N}, \mathrm{P}, \mathrm{K}, \mathrm{Mg}$, $\mathrm{Ca}$ and other nutrients. The following raw materials are used to produce the digestive fluid Delta-D and the Mineral Powder Mix which is used to neutralize the slurry. One of the most important properties of Delta-D is that it only catalyses digestion, which means that after the digestion process is over the Delta-D originally added will remain in the system and it is possible to use the Delta- D to digest more and more organic matter.

Raw Materials used to Produce the Digestive Fluid Eppawela Rock Phosphate (Apatite), Phosphoric Acid, Sulphuric Acid, Nitric Acid, Acetic Acid, Citric Acid, Sugar, Starch, Fruit and Vegetable Waste, Fish Waste, Saw Dust, Rice Straw or Paddy Husk.

Raw Materials used to Produce the Mineral Powder Mix

Eppawela Rock Phosphate (Apatite), Dolomite, Calcite, Powdered Mica, Powdered Quartz, Mixed Salt from Sea Bitterns, Iron Ore, Foundry Slag, Zinc Ore, etc.

\subsection{How Does Delta-D Digest Organic Matter? $(1,3,4,5)$}

Delta-D has a chemical combination that can digest all types of natural organic matter by carrying out the following reactions. One of its major features is to initiate catabolism (breaking down) of complex carbohydrates, proteins, etc., with acidic action and subsequently mobilize enzymes available in organic matter, as well as, enzymes secreted by microorganisms to continue the process.

1.Dehydration.

2. Hydration.

3. Oxidation.

3. Breaking down of complex molecules, such as, cellulose, starch, proteins, oils and fats.

4.. Converting organic, N, P, K, Ca, M, Na, Fe, $\mathrm{Mn}, \mathrm{Mo}$, etc. into inorganic, water soluble forms.
8.2 Demonstrations of Delta-D Technology Carried Out In Sri Lanka

Delta-D Technology has been demonstrated at several government institutions, such as, The Institution of Engineers of Sri Lanka, Ministry of Agriculture (Govijana Mandiraya) University of Moratuwa, Horana Urban Council, Maharagama Urban Council, Lanka Phosphates Ltd., The Central Environmental Authority, and several leading private companies, such as, The Lodge Habarana, The Confifi Group of Hotels, Pussellawa plantations, Horana Plantations, CIC Fertilisers, Keells Food Products, Nelna Farm, Mandarin Farm and several other poultry farms. Presentations and demonstrations have been, made at the Mahaweli Ministry, at a workshop organized by Janatha Fertiliser Enterprises, attended by Hon. Chamal Rajapakse, Minister of Agricultural Development and 60 personnel comprising Mayors and Chairmen of MCs, UCs and PCs in the Southern Province. A demonstration was also carried out at The Central Environmental Authority, Parisara Piyasa, Battaramulla, on behalf of the Horana Urban Council to obtain CEA approval for a plant to be constructed at Horana. The process has been tested with all types of biomass and the fertilizer produced has been tested by cultivating, rice, vegetables and fruits successfully. With the support of the Janatha Fertiliser Enterprises, a corporation under the Ministry of Agricultural Development, around 1330 entrepreneurs have been trained to convert rice straw into organic fertilizer using this technology. The technology has been introduced to several local authorities to rapidly convert USW into organic fertilizer.

8.3 Presentation Of Delta-D Technology At National and International Conferences

The author attended the $22^{\text {nd }}$ International Conference on Solid Waste Technology and Management, conducted by The Widener University, Philadelphia, USA, during the period 18-21 March 2007 and presented two research papers on conversion of solid waste into organic fertilizer. The author also attended the $23^{\text {rd }}$ International Conference on Solid Waste Technology and Management, conducted by The Widener University, Philadelphia, USA, during the period $30^{\text {th }}$ March to $2^{\text {nd }}$ April 2008 and presented one research paper on conversion of solid waste into organic fertilizer using Delta-D 
Technology. The author in collaboration with two other authors presented one research paper at the First International Conference on Solid and Rock Engineering held in 2007 August in Colombo, Sri Lanka, conducted by The Geotechnical Society of Sri Lanka. The author also presented one research paper on Delta-D Technology at the Annual Sessions of The Institution of Engineers Sri Lanka, held in October 2007. Titles of these research papers are given in the list of references.

\subsection{Recommended Methods For Using Delta-} D Technology To Produce Organic Fertiliser

Research conducted by the author on waste material, such as, rice straw, farm waste and market waste has lead to the development of the following methods of using Delta-D Technology to produce organic fertilizer..

(A) The Recommended Method For Rapid Digestion Of Rice Straw In Dry Zones Making

Maximum Use Of Long Periods Of Sunshine

1) $35 \mathrm{~kg}$ of dry rice straw is wetted with a solution of 1litre of Delta-D mixed with 50 litres of water.

2) The wetted straw is laid on plastic sheets and exposed to the sun for 3 days.

3 ) After 3 days the straw crumbles into powder.

4) The $35 \mathrm{~kg}$ of digested straw is wetted with 10 litres of water and is mixed with $5 \mathrm{~kg}$ of

Eppawela Rock Phosphate (ERP) and stored for 2 days.

5) The mixture produced in step 4 is mixed with 500g of Dolomite (D).

6) Now the product is ready for use as the first fertiliser application for paddy cultivation.

7) For other annual crops and perennial crops, the composition of the fertilizer can be adjusted by

adding plant and animal wastes digested with Delta-D to the digested straw.

(B) The Recommended Method For Rapid Digestion Of Rice Straw In Wet Zones.

Even in the wet zones of Sri Lanka there is ample sun shine right through the year. Hence, Method A can be practiced most of the time. However, if there are rains and it is not possible to expose the straw to sunshine, the following method should be followed.
1) $35 \mathrm{~kg}$ of dry rice straw is wetted with a solution of 2 litres of Delta-D mixed with 50 litres of water.

2) The wetted straw is stored in a dry area for 5 days.

3) After 5 days the straw crumbles into powder.

4) The $35 \mathrm{~kg}$ of digested straw is wetted with 10 litres of water and is mixed with $10 \mathrm{~kg}$ of ERP and stored for 2 days.

5) The mixture produced in step 4 is mixed with $1 \mathrm{~kg}$ of $\mathrm{D}$.

6) Now the product is ready for use as the first fertiliser application for paddy cultivation.

7) For other annual crops and perennial crops, the composition of the fertilizer can be adjusted by

adding plant and animal wastes digested with Delta-D to the digested straw.

(C) The Recommended Method For Rapid Digestion Of Poultry, Cattle and Pig Farm Waste

1) Excreta of animals, including urine is collected and mechanically mixed into a slurry.

2) Per 100 liters of the slurry, $30 \mathrm{~kg}$ of, sawdust, straw or any other type of dry cellulose material

is added and well mixed.

3) 2 liters of Delta-D is added to the above mix and allowed to react for 5 days.

4) After 5 days, $10 \mathrm{~kg}$ of ERP is mixed to it and allowed to react for 2 days.

5) The mixture produced in step 4 is mixed with $1 \mathrm{~kg}$ of Dolomite.

6) Now the product is ready for use.

(D) The Recommended Method For Rapid Digestion Of Fruit And Vegetable Waste (FVW)

1) FVW is chopped to a size below $25 \mathrm{~mm}(\mathrm{~L}) \mathrm{x}$ $25 \mathrm{~mm}(\mathrm{~W}) \times 5 \mathrm{~mm}(\mathrm{~T})$.

2) Per $50 \mathrm{~kg}$ of FVW, 1 liter of Delta-D is added, well mixed and allowed to react for 2 days...

3) After 2 days $20 \mathrm{~kg}$ of dry saw dust is mixed with the slurry and allowed to react for 2 days 4) After 2 days $5 \mathrm{~kg}$ of ERP is mixed to it and allowed to react for 2 days.

4) The mixture produced in step 4 is mixed with $1 \mathrm{~kg}$ of Dolomite.

$5)$ Now the product is ready for use.

Table- 1 and Table- 2 give the chemical analysis of organic fertilizer produced from straw and 
combinations of straw, cow dung, poultry dung and fruit and vegetable waste using the above procedure.

\section{The Research Project on Delta-D Initiated Microorganic Digestion of Saw Dust into Organic Fertiliser}

The main objective of the research project was to study the rates of biodegradation of different species of SD, under different moisture contents and under the influence of fish and vegetable market waste digested by Delta-D.

9.1 Equipment, Instruments, Materials and Methods:

\subsubsection{Equipment and Instruments}

SD had to be digested in containers, to control the moisture content and to measure the temperature. It was decided to use 200 liter plastic barrels, cut into half to obtain half barrels of capacity around 100 liters each. These were thoroughly washed with detergents and water to ensure the absence of materials toxic to microorganisms. The cylindrical walls of barrels were perforated, from top to bottom, at 6" intervals vertically and horizontally, with a $8 \mathrm{~mm}$ drilling tool, in order to provide air to microorganisms. A 250 $\mathrm{kg}$ Avery Platform Weighing Scale was used for weighing of material. A Mercury Thermometer of range $0^{\circ} \mathrm{C}-100^{\circ} \mathrm{C}$ was used to measure temperatures.

\subsubsection{Material}

SD produced out of wood species, Jack (J), Mahogany (M), Teak (T) and Rubber (R), were separately collected into bags from the Linton Saw Mill, located $1 \mathrm{~km}$ away from the research station. In order to ensure that chemicals were not present, SD due to sawing of logs were collected.

9.2 Digestion of Fish and Vegetable Waste using Delta-D

Fish market waste and vegetable market wastes were collected from the Panadura Market. Fish waste consisted of heads, skins, fins, bones, bowels, etc. Vegetable waste mainly consisted of rotten cabbage, leeks, radish, salad leaves, carrots etc. $100 \mathrm{~kg}$ of fish waste was digested with 2 liters of Delta-D, to obtain fish waste slurry (FWS). $100 \mathrm{~kg}$ of vegetable waste was digested with 2 liters of Delta-D, to obtain a vegetable waste slurry (VWS). FWS and VWS were thoroughly mixed together to obtain around $206 \mathrm{~kg}$ of mixed slurry (MS). The dry solid content of MS was measured by drying a sample of $20 \mathrm{~g}$ of well mixed MS using a UV Lamp Moisture Balance and was found to be around $32 \%$. Hence, $5 \mathrm{~kg}$ of MS contained $1.6 \mathrm{~kg}$ solids and $3.4 \mathrm{~kg}$ of water. For convenience it was assumed that there were no components with boiling points below $105^{\circ} \mathrm{C}$, other than water.

9.3 Preparation of Saw Dust (SD) Samples for the Research Project

From SD of each of the wood species, six (6) 25 $\mathrm{kg}$ samples were taken and filled into six (6) 100 liter barrels. Water and MS were added to SD and thoroughly mixed as given in Table 3. In Table 3, $\mathrm{T}_{11}, \mathrm{~T}_{2 \mathrm{f}}, \mathrm{T}_{3 \mathrm{l}}, \mathrm{T}_{4 \mathrm{f}}, \mathrm{T}_{55}, \mathrm{~T}_{6 \mathrm{l}} ; \mathrm{T}_{1 \mathrm{M}}, \mathrm{T}_{2 \mathrm{M}}$, $\mathrm{T}_{3 \mathrm{M}}, \mathrm{T} 4 \mathrm{M}, \mathrm{T}_{5 \mathrm{M}}, \mathrm{T}_{6 \mathrm{M}}, \ldots$. etc., refer to samples prepared by mixing variable quantities of water and MS to SD species, Jack, Mahogany, etc. All the barrels were covered with clear transparent polythene of 200 gauge thickness, perforated at $6 "$ intervals, to prevent excessive moisture loss without compromising microbial respiration. The thirty (30) samples were kept in a cool place in a building with an asbestose roof covered on three (3) sides, in order to prevent excessive moisture loss due sunlight and wind.

9.4 Moisture Control, Temperature Measurement and Data Analysis

Since a sufficient moisture content $(\mathrm{M})$ is required for bacterial activity in composting, $M$ had to be maintained at a constant level. The method adopted was to take the weight of each barrel after adding water and MS (as per Table 3) and to mark it on each barrel as the weight on the first day of the experiment. Once in.5 days, each barrel was weighed and tne weight difference (WD) was calculated by deducting the current weight from the weight on the first day. WD was considered to be the moisture loss (ML) due to evaporation and an equal amount of water was added and mixed with SD in each barrel to compensate for ML On days when ML was compensated, temperature readings were not taken.

As described in Section 7.0 - Fundamentals of Composting, whenever there is aerobic micro organic activity, the temperature $(\mathrm{T})$ in the 
compost pile rises above ambient temperature. Hence, temperature $(\mathrm{T})$ at the centre of each $S D$ barrel was measured at 12.00 hrs each day for a period of time until the temperature reached ambient temperature. Table 5 and Table 6 give the readings of temperature with time for all the samples. From Tables 4 and 5, it is quite evident that there was no appreciable temperature rise in samples of SD which did not contain MS, indicating negligible aerobic microbial activity in the samples. However, in samples of SD which contained MS, the temperatures rose significantly, indicating strong aerobic microbial activity. For all species of SD the highest temperatures recorded were for samples which had MS and $50 \%$ moisture. The temperatures recorded for samples which had MS, but lower moisture (40\% and $45 \%$ ) contents, the temperatures were lower than for $50 \%$ moisture. The highest temperature of $56^{\circ} \mathrm{C}$ was recorded in Rubber SD with MS and 50\% moisture, which indicated highest aerobic micro organic activity, compared to other samples. For all samples of SD with MS, the temperatures reached maximum values within 30 days and temperatures started dropping within 40 days, clearly indicating that the composting process is initiated and accelerated by MS.

\subsection{Manufacture of Organic Fertiliser from MS Digested Saw Dust}

The final step in the manufacture of OF from SD digested with MS was to mix Eppawela Rock Phosphate (ERP) and Dolomite (D) as given in Table 2, which is, Delta-D : ERP : Dolomite $=1 \mathrm{~L}: 5 \mathrm{~kg}: 1 \mathrm{~kg}$. Since, $5 \mathrm{~kg}$ of MS which contains $200 \mathrm{ml}$ Delta-D was add to each barrel, the quantities of ERP and Dolomite to be added to each barrel were $1 \mathrm{~kg}$ and $200 \mathrm{~g}$ respective. After addition of ERP and D the SD was thoroughly mixed and allowed to react for 3 days. The product

\section{Agricultural Trials Conducted to Check the Suitability of the Organic Fertiliser}

The suitability of the MS Digested Organic Fertilizer (MSOF) produced was tested by applying to mature plants and tender plants of, fruit varieties; Papaya, Guava, Mango and Ambarella and vegetable varieties, ladies fingers, egg plant, capsicum, slender gourd, bitter gourd and long beans.

\subsection{Results}

When MSOF was applied to mature and tender plants of fruit varieties: Papaya, Guava, Mango and Ambarella and vegetable varieties: ladies fingers, egg plant, capsicum, slender gourd, bitter gourd and long beans in both fruits and vegetables, there was significant enhancement of growth rate, which was evident from, new offshoots of branches springing up within 1 week and continuing to grow unhindered. The colour of leaves were dark green showing that there was no nitrogen or magnesium deficiency. At present, a study comparing the performance of MSOF with traditional $\mathrm{N}, \mathrm{P}, \mathrm{K}, \mathrm{Mg}$ fertiliser is underway of which results will be available in December 2009. The data will be published during the first quarter of 2009.

\section{Economical Feasibility of Composting Saw Dust by the Combined Process of Delta-D Technology and Aerobic Micro Organic Activity}

Results of the research project clearly indicate that it is technically possible to produce OF from SD using the above process. In order to see whether the process is economically viable, it is necessary to estimate the capital cost required and the operational costs.

\subsection{Capital Cost}

The process consists of the following three main operations, which can be carried out manually or mechanically.

(a) Digestion of, fish (animal) waste and fruit and vegetable waste using Delta-D to produce Mixed Slurry (MS) -

This operation requires, several $200 \mathrm{~L}$ Plastic Barrels. Each barrel costs around Rs.1200 and can produce $200 \mathrm{~kg}$ of MS per 2 days.

(b) Mixing water and MS with SD - This can be carried out manually using shovels.

(c) Final mixing of ERP and Dolomite - This operation can be carried out manually using shovels.

(d) Weighing and storage of raw materials, as well as, weighing, packing, storage and sale of finished product.

If the production per day is below 5 TPD, manual operations can be carried out and the 
capital costs will be minimal. However if larger production capacities are required, operations can be carried out using electric motor or engine driven mechanical mixers, which will require capital in proportion to the plant capacity. Since, Capital Cost varies with the degree of mechanization, costs of land, buildings and other infrastructural requirements, this aspect is not discussed under this section.

\subsection{Operational Costs - and Economic Feasibility}

The operational costs, profits and the feasibility of manufacturing OF is summarized in Table 4. Operational costs consist of Direct Costs (direct raw material, packing material and labour requirements) and Overheads. In the following analysis, all costs other than Direct Costs have bee lumped into Overheads.

\section{Conclusions}

1. Saw dust (SD) cannot be composted with only moisture, since naturally occurring microorganisms are incapable of secreting enzymes that could break down components in SD.

2. Delta-D initiated micro organic digestion of SD into organic fertilizer (OF) is a technically, economically and environmentally feasible solution to the SD problem in Sri Lanka, since, composting can be done fast and the OF can be sold at a low price even with a profit margin, benefiting the producer of OF and the farmers. The GOSL can reduce the annual cost of urea fertilizer subsidy and the environment hitherto polluted due to haphazard dumping or burning of saw dust can be conserved. .

3. Since, saw dust and similar high cellulose material, such as, straw, paddy husk, leaves of plants, grass, weeds, etc., are available all over the country, production of organic fertilizer can be decentralized, so that
OF is produced in agricultural areas, which reduces, capital cost, working capital, operational costs and transport, there by further reducing fertilizer costs.

4. Since most imported chemical fertilizers prices (CFP) are sensitive to crude oil prices (COP). With rising COP, CFP too will increase in the future. However, since the raw materials required for OF are locally available, OF prices will remain stable.

5. More self employment type jobs will be created if OF industry is mooted by the GOSL and the private sector.

\section{Acknowledgements}

I take pleasure in thanking all those who helped me to carryout this research project, namely, Ranjani Perera - Manager, Charith Perera - Partner, Maheshika Perera - Partner, M. Alahudeen - Foreman, A. Hassan - Plant Operator, S. Sampath - Plant Operator, Dayawathie Fernando and Deulet Fernando (employees) of Sea way Enterprises of Panadura. 
Table 1 - Chemical Analysis of Organic Fertiliser Produced from Straw, Cow Dung and Poultry Dung Using Delta-D Technology As First Application For Paddy Cultivation

\begin{tabular}{|l|l|l|l|}
\hline Component & Straw Only & $90 \%$ Straw $+10 \%$ Cowdung & $90 \%$ Straw $+10 \%$ Poultrydung \\
\hline Moisture\% & 30.0 & 30.0 & 30.0 \\
\hline $\begin{array}{l}\text { Organic } \\
\text { Carbon }\end{array}$ & 28.5 & 28.7 & 28.9 \\
\hline Total $\mathrm{N}_{\%}$ & 0.60 & 1.27 & 1.83 \\
\hline Total $\mathrm{P}_{2} \mathrm{O}_{5} \%$ & 6.80 & 7.10 & 7.80 \\
\hline Total $\mathrm{K}_{2} \mathrm{O} \%$ & 1.40 & 1.60 & 1.87 \\
\hline
\end{tabular}

Table 2 - Chemical Analysis of Organic Fertiliser Produced from PL and FVW

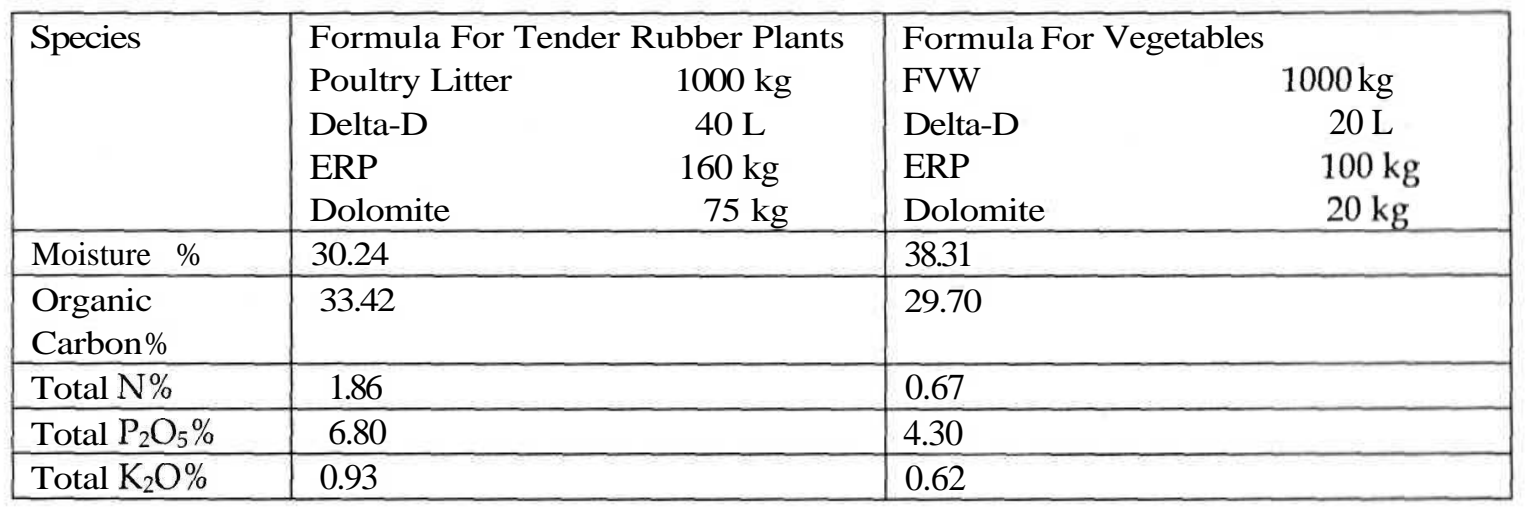

Table 3- Wood Species and Type of Treatment

\begin{tabular}{|c|c|c|c|c|c|c|}
\hline $\begin{array}{l}\text { Wood } \\
\text { Species }\end{array}$ & $\begin{array}{l}\text { SD: } \mathrm{H}_{2} \mathrm{O}: \mathrm{MS} \\
\text { Ratio=25:16:0 } \\
\mathrm{H}_{2} \mathrm{O}=40 \%\end{array}$ & $\begin{array}{l}\mathrm{SD}: \mathrm{H}_{2} \mathrm{O}: \mathrm{MS} \\
\text { Ratio }=25: 20: 0 \\
\mathrm{H}_{2} \mathrm{O}=45 \%\end{array}$ & $\begin{array}{l}\text { SD: } \mathrm{H}_{2} \mathrm{O}: M S \\
\text { Ratio=25:25:0 } \\
\mathrm{H}_{2} \mathrm{O}=50.00 \%\end{array}$ & $\begin{array}{l}\text { SD: } \mathrm{H}_{2} \mathrm{O}: \mathrm{MS} \\
\text { Ratio=25:12.6:5 } \\
\mathrm{H}_{2} \mathrm{O}=40 \%\end{array}$ & $\begin{array}{l}\text { SD: } \mathrm{H}_{2} \mathrm{O}: \mathrm{MS} \\
\text { Ratio }=25: 16.6: 5 \\
\mathrm{H}_{2} \mathrm{O}=45 \%\end{array}$ & $\begin{array}{l}\mathrm{SD}: \mathrm{H}_{2} \mathrm{O}: \mathrm{MS} \\
\text { Ratio=25:21.6:5 } \\
\mathrm{H}_{2} \mathrm{O}=50.00 \%\end{array}$ \\
\hline Jack & $\begin{array}{l}\text { Water } 16 \mathrm{~kg} \\
\text { added to } 25 \mathrm{~kg} \\
\text { of Dry SD. } \\
\text { Sample No: } \\
\mathrm{T}_{1 \mathrm{~J}}\end{array}$ & $\begin{array}{l}\text { Water } 20 \mathrm{~kg} \\
\text { added to } 25 \mathrm{~kg} \\
\text { of Dry SD } \\
\text { Sample No: } T_{2 J}\end{array}$ & $\begin{array}{l}\text { Water } 25 \mathrm{~kg} \\
\text { added to } 25 \mathrm{~kg} \\
\text { of Dry SD } \\
\text { Sample No: } \mathrm{T}_{3 \mathrm{~J}}\end{array}$ & 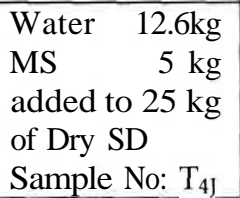 & $\begin{array}{l}\text { Water } 16.6 \mathrm{~kg} \\
\text { MS } 5 \mathrm{~kg} \\
\text { added to } 25 \mathrm{~kg} \\
\text { of Dry SD } \\
\text { Sample No: } \mathrm{T}_{5 \mathrm{~J}}\end{array}$ & $\begin{array}{l}\text { Water } 21.6 \mathrm{~kg} \\
\text { MS } 5 \mathrm{~kg} \\
\text { added lo } 25 \mathrm{~kg} \\
\text { of Dry SD } \\
\text { Sample No: } T_{6 \mathrm{~J}}\end{array}$ \\
\hline Mahogany & $\begin{array}{l}\text { Water } 16 \mathrm{~kg} \\
\text { added to } 25 \mathrm{~kg} \\
\text { of Dry SD. } \\
\text { Sample No: } \\
\mathrm{T}_{1 \mathrm{M}}\end{array}$ & $\begin{array}{l}\text { Water } 20 \mathrm{~kg} \\
\text { added to } 25 \mathrm{~kg} \\
\text { of Dry SD } \\
\text { Sample No: } \\
\mathrm{T}_{2 \mathrm{M}}\end{array}$ & $\begin{array}{l}\text { Water } 25 \mathrm{~kg} \\
\text { added to } 25 \mathrm{~kg} \\
\text { of Dry SD } \\
\text { Sample No: } \\
\mathrm{T}_{3 \mathrm{M}}\end{array}$ & $\begin{array}{l}\text { Water } 12.6 \mathrm{~kg} \\
\text { MS } 5 \mathrm{~kg} \\
\text { added to } 25 \mathrm{~kg} \\
\text { of Dry SD } \\
\text { Sample } \quad \text { No: } \\
\text { T4M }\end{array}$ & $\begin{array}{l}\text { Water } 16.6 \mathrm{~kg} \\
\text { MS } 5 \mathrm{~kg} \\
\text { added to } 25 \mathrm{~kg} \\
\text { of Dry SD } \\
\text { Sample } \\
\text { To: } \\
\text { TM }\end{array}$ & $\begin{array}{l}\text { Water } 21.6 \mathrm{~kg} \\
\text { MS } 5 \mathrm{~kg} \\
\text { added lo } 25 \mathrm{~kg} \\
\text { of Dry SD } \\
\text { Sample } \\
\mathrm{T}_{6 \mathrm{M}}\end{array}$ \\
\hline Teak & $\begin{array}{l}\text { Water } 16 \mathrm{~kg} \\
\text { added to } 25 \mathrm{~kg} \\
\text { of Dry SD. } \\
\text { Sample No: } \\
\mathrm{T}_{1 \mathrm{~T}}\end{array}$ & $\begin{array}{l}\text { Water } 20 \mathrm{~kg} \\
\text { added to } 25 \mathrm{~kg} \\
\text { of Dry SD } \\
\text { Sample No: } T_{2 T}\end{array}$ & $\begin{array}{l}\text { Water } 25 \mathrm{~kg} \\
\text { added to } 25 \mathrm{~kg} \\
\text { of Dry SD } \\
\text { Sample No: } T_{3 T}\end{array}$ & $\begin{array}{l}\text { Water } 12.6 \mathrm{~kg} \\
\text { MS } 5 \mathrm{~kg} \\
\text { added to } 25 \mathrm{~kg} \\
\text { of Dry SD } \\
\text { Sample } \mathrm{No} \mathrm{T}_{4 \mathrm{~T}}\end{array}$ & $\begin{array}{l}\text { Water } 16.6 \mathrm{~kg} \\
\text { MS } 5 \mathrm{~kg} \\
\text { ded to } 25 \mathrm{~kg} \text { of } \\
\text { Dry SD } \\
\text { Sample No: TST }\end{array}$ & $\begin{array}{l}\text { Water } 21.6 \mathrm{~kg} \\
\text { MS } 5 \mathrm{~kg} \\
\text { added lo } 25 \mathrm{~kg} \\
\text { of Dry SD } \\
\text { Sample No: } \mathrm{T}_{6 \mathrm{~T}}\end{array}$ \\
\hline Rubber & $\begin{array}{l}\text { Water } 16 \mathrm{~kg} \\
\text { added to } 25 \mathrm{~kg} \\
\text { of Dry SD. } \\
\text { Sample No: } \\
\mathrm{T}_{1 \mathrm{R}}\end{array}$ & $\begin{array}{l}\text { Water } 20 \mathrm{~kg} \\
\text { added to } 25 \mathrm{~kg} \\
\text { of Dry SD } \\
\text { Sample No: } T_{2 R}\end{array}$ & $\begin{array}{l}\text { Water } 25 \mathrm{~kg} \\
\text { added to } 25 \mathrm{~kg} \\
\text { of Dry SD } \\
\text { Sample No: } T_{3 R}\end{array}$ & $\begin{array}{l}\text { Water } 12.6 \mathrm{~kg} \\
\text { MS } 5 \mathrm{~kg} \\
\text { added to } 25 \mathrm{~kg} \\
\text { of Dry SD } \\
\text { Sample No: } \mathrm{T}_{4 \mathrm{R}}\end{array}$ & $\begin{array}{l}\text { Water } 16.6 \mathrm{~kg} \\
\text { MS } 5 \mathrm{~kg} \\
\text { added to } 25 \mathrm{~kg} \\
\text { of Dry SD } \\
\text { Sample } \\
\text { No: } T_{5 R}\end{array}$ & $\begin{array}{l}\text { Water } 21.6 \mathrm{~kg} \\
\text { MS } 5 \mathrm{~kg} \\
\text { added to } 25 \mathrm{~kg} \\
\text { of Dry SD } \\
\text { Sample No: } T_{6 \mathrm{R}}\end{array}$ \\
\hline
\end{tabular}


Table 4- Feasibility of Composting SD by Combined Process of Delta-D Technology \& Aerobic Microorganism

\begin{tabular}{|c|c|c|c|c|}
\hline $\begin{array}{l}\text { Raw Materials and } \\
\text { Labour Required } \\
\text { Manufacture } \\
\text { Slurry (MS) }\end{array}$ & Quantities & $\begin{array}{ll}\text { Unit } & \text { Cost } \\
\text { (includes } & \\
\text { collection, } & \\
\text { handling } & \text { and } \\
\text { transport) } & \end{array}$ & Costs / Profits & \\
\hline $\begin{array}{l}\text { Fish Waste } \\
\text { Vegetable Waste } \\
\text { Delta-D } \\
\text { Labour it is assumed } \\
\text { that } 1 \text { labour unit is } \\
\text { sufficiwnt to produce } \\
200 \text { (MS) }\end{array}$ & $\begin{array}{l}100 \mathrm{~kg} \\
100 \mathrm{~kg} \\
4 \mathrm{~L} \\
1 \text { Unit }\end{array}$ & $\begin{array}{l}\text { Rs. } 5.00 \text { per kg } \\
\text { Rs. } \quad 5.00 \text { per kg } \\
\text { Rs. } 200.00 \text { per L } \\
\text { Rs. } \quad 700.00 \text { per } \\
\text { Unit }\end{array}$ & $\begin{array}{l}\text { Total Cost to Produce } 206 \mathrm{~kg} \mathrm{MS} \\
\text { Total Cost to Produce } 1 \mathrm{~kg} \mathrm{MS}\end{array}$ & $\begin{array}{r}\text { Rs. } 500.00 \\
\text { Rs. } 500.00 \\
\text { Rs. } 800.00 \\
\text { Rs. } 700.00 \\
-\quad \\
\text { Rs. } 2500.00 \\
\text { Rs. } \quad 12.50\end{array}$ \\
\hline $\begin{array}{lr}\text { Raw Materials } & \text { and } \\
\text { Labour Required } & \text { To } \\
\text { Manufacture 50 } & \mathrm{kg} \\
\text { Organic Fertiliser (OF) } \\
\text { from Saw Dust }\end{array}$ & Quantities & $\begin{array}{ll}\text { Unit } & \text { Cost } \\
\text { (includes } & \\
\text { collection, } & \\
\text { handling } & \text { and } \\
\text { transport) } & \end{array}$ & & Cost \\
\hline $\begin{array}{l}\text { Water } \\
\text { Mixed Slurry } \\
\text { Dry Saw Dust } \\
\text { ERP } \\
\text { Dolomite (D) } \\
\text { Labour (it is assumed } \\
\text { that } 1 \text { labour unit is } \\
\text { sufficient to produce } \\
250 \mathrm{~kg} \text { ) } \\
\text { Packing Material } 25 \mathrm{~kg} \\
\text { PP }\end{array}$ & $\begin{array}{c}21.6 \mathrm{~L} \\
5.0 \mathrm{~kg} \\
25.0 \mathrm{Kg} \\
2.0 \mathrm{~kg} \\
0.4 \mathrm{~kg} \\
1 / 5 \quad \mathrm{Unit} \\
\\
\\
2 \mathrm{Bags}\end{array}$ & $\begin{array}{lc}\text { Rs. } & 0.20 \text { per L } \\
\text { Rs. } & 12.50 \text { per kg } \\
\text { Rs. } & 5.00 \text { per kg } \\
\text { Rs. } & 10.00 \text { per kg } \\
\text { Rs. } & 5.00 \text { per kg } \\
\text { Rs. } & 700.00 \text { per } \\
\text { Unit }\end{array}$ & $\begin{array}{l}\text { Total Direct Costs to Produce } 50 \mathrm{~kg} \\
\text { Total Direct Costs to Produce } 1 \mathrm{~kg} \\
\text { Cost of Overheads } 31 \% \text { per kg } \\
\text { Total Cost to Produce } 1 \mathrm{~kg} \\
\text { Proposed Selling Price } \\
\text { Profit per kg } \\
\text { If production capacity is } 1 \mathrm{TPD} \text {, pro } \\
\text { be Rs. } 5000 \text { and the profit per year } \\
\text { Rs. } 1,500,000 \text {. }\end{array}$ & 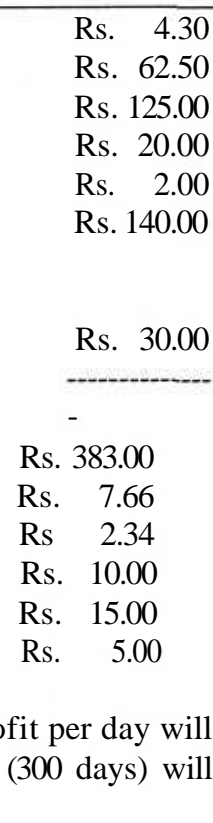 \\
\hline
\end{tabular}


Table 5 - Time (Days) Vs Temperature $\left({ }^{\circ} \mathrm{C}\right)$ Readings For Jack SD and Mahogany SD

\begin{tabular}{|c|c|c|c|c|c|c|c|c|c|c|c|c|}
\hline $\begin{array}{l}\text { Time } \\
\text { Days }\end{array}$ & $\begin{array}{l}\mathbf{T}_{1 \mathrm{j}} \\
\mathrm{T}^{\circ} \mathrm{C}\end{array}$ & $\begin{array}{l}\mathrm{T}_{2 \mathrm{~J}} \\
\mathrm{~T}^{0} \mathrm{C}\end{array}$ & $\begin{array}{l}\mathrm{T}_{3 \mathrm{~J}} \\
\mathrm{~T}^{\circ} \mathrm{C}\end{array}$ & $\begin{array}{l}\mathrm{T} 4 \mathrm{~J} \\
\mathrm{~T}^{0} \mathrm{C}\end{array}$ & $\begin{array}{l}\mathrm{T}_{5 \mathrm{~J}} \\
\mathrm{~T}^{0} \mathrm{C}\end{array}$ & $\begin{array}{l}\mathrm{T}_{\text {GJ }} \\
\mathrm{T}^{\circ} \mathrm{C}\end{array}$ & $\begin{array}{l}\mathrm{T}_{1 \mathrm{M}} \\
\mathrm{T}^{0} \mathrm{C}\end{array}$ & $\begin{array}{l}\text { T2M } \\
\mathrm{T}^{\circ} \mathrm{C}\end{array}$ & $\begin{array}{l}\mathrm{T}_{3 \mathrm{M}} \\
\mathrm{T}^{0} \mathrm{C}\end{array}$ & $\begin{array}{l}\mathrm{T}_{4 \mathrm{M}} \\
\mathrm{T}^{0} \mathrm{C}\end{array}$ & $\begin{array}{l}\mathrm{T}_{5 \mathrm{M}} \\
\mathrm{T}^{0} \mathrm{C}\end{array}$ & $\begin{array}{l}\mathrm{T}_{6 \mathrm{M}} \\
\mathrm{T}^{0} \mathrm{C}\end{array}$ \\
\hline 1 & 28 & 28 & 28 & 28 & 28 & 28 & 28 & 28 & 28 & 28 & 28 & 28 \\
\hline 2 & 28 & 28 & 28 & 33 & 35 & 35 & 28 & 28 & 28 & 30 & 33 & 35 \\
\hline 3 & 28 & 28 & 28 & 40 & 42 & 45 & 28 & 28 & 28 & 33 & 38 & 45 \\
\hline 4 & 28 & 28 & 28 & 42 & 46 & 50 & 28 & 28 & 28 & 35 & 42 & 50 \\
\hline 5 & 28 & 28 & 28 & 42 & 46 & 50 & 29 & 28 & 28 & 38 & 43 & 50 \\
\hline 7 & 29 & 29 & 29 & 43 & 46 & 50 & 29 & 29 & 29 & 40 & 43 & 50 \\
\hline 8 & 29 & 29 & 29 & 43 & 46 & 50 & 29 & 29 & 29 & 42 & 43 & 50 \\
\hline 9 & 29 & 29 & 29 & 44 & 47 & 50 & 29 & 29 & 29 & 43 & 44 & 50 \\
\hline 10 & 29 & 29 & 29 & 44 & 47 & 50 & 29 & 29 & 29 & 43 & 44 & 50 \\
\hline $\begin{array}{ll}11 \\
\end{array}$ & 29 & 29 & 29 & 44 & 47 & 50 & 29 & 29 & 29 & 45 & 44 & 50 \\
\hline 13 & 29 & 29 & 29 & 47 & 48 & 51 & 29 & 29 & 29 & 45 & 46 & 51 \\
\hline 14 & 29 & 29 & 29 & 47 & 48 & 51 & 29 & 29 & 29 & 45 & 48 & 51 \\
\hline 15 & 29 & 29 & 29 & 47 & 49 & 51 & 29 & 29 & 29 & 45 & 48 & 51 \\
\hline 16 & 29 & 29 & 29 & 47 & 49 & 51 & 29 & 29 & 29 & 45 & 48 & 51 \\
\hline 17 & 31 & 31 & 31 & 47 & 49 & 51 & 31 & 31 & 31 & 45 & 49 & 51 \\
\hline 19 & 31 & 31 & 31 & 47 & 51 & 51 & 31 & 31 & 31 & 45 & 49 & 51 \\
\hline 20 & 31 & 31 & 31 & 47 & 52 & 52 & 31 & 31 & 31 & 45 & 49 & 52 \\
\hline 21 & 31 & 31 & 31 & 48 & 52 & 52 & 31 & 31 & 31 & 45 & 49 & 52 \\
\hline 22 & 31 & 31 & 31 & 48 & 52 & 52 & 31 & 31 & 31 & 45 & 50 & 52 \\
\hline 23 & 31 & 31 & 31 & 48 & 52 & 52 & 31 & 31 & 31 & 45 & 50 & 52 \\
\hline 25 & 31 & 31 & 31 & 48 & 52 & 53 & 31 & 31 & 31 & 45 & 50 & 53 \\
\hline 26 & 31 & 31 & 31 & 48 & 52 & 53 & 31 & 31 & 31 & 45 & 50 & 53 \\
\hline 27 & 31 & 31 & 31 & 48 & 52 & 53 & 31 & 31 & 31 & 45 & 50 & 53 \\
\hline 28 & 31 & 31 & 31 & 48 & 52 & 53 & 31 & 31 & 31 & 45 & 50 & 53 \\
\hline 29 & 31 & 31 & 31 & 48 & 52 & 53 & 31 & 31 & 31 & 46 & 50 & 53 \\
\hline 31 & $\frac{1}{32}$ & 32 & 32 & 48 & 52 & 53 & 32 & 31 & $\frac{1}{32}$ & 46 & 50 & 53 \\
\hline 32 & 32 & 32 & 32 & 48 & 52 & 53 & 32 & 32 & 32 & 46 & 50 & 53 \\
\hline 33 & 32 & 32 & 32 & 48 & 52 & 53 & 32 & 32 & 32 & 46 & 50 & 53 \\
\hline 34 & 32 & 32 & 32 & 48 & 52 & 53 & 32 & 32 & 32 & 46 & 50 & 53 \\
\hline 35 & 32 & 32 & 32 & 48 & 50 & 53 & 32 & 32 & 32 & 46 & 50 & 53 \\
\hline 37 & 32 & 32 & 32 & 48 & 50 & 50 & 32 & 32 & 32 & 46 & 50 & 50 \\
\hline 38 & 31 & 31 & 31 & 48 & 50 & 50 & 31 & 31 & 31 & 46 & 50 & 50 \\
\hline 39 & 31 & 31 & 31 & 48 & 49 & 49 & 31 & 31 & 31 & 46 & 48 & 49 \\
\hline 40 & 31 & 31 & 31 & 48 & 49 & 49 & 31 & 31 & 31 & 46 & 48 & 49 \\
\hline 41 & 31 & 31 & 31 & 48 & 48 & 49 & 31 & 31 & 31 & 46 & 46 & 49 \\
\hline 43 & 31 & 31 & 31 & 47 & 48 & 48 & 31 & 31 & 31 & 46 & 45 & 48 \\
\hline 44 & 31 & 31 & 31 & 47 & 46 & 44 & 31 & 31 & 31 & 46 & 43 & 44 \\
\hline 45 & 31 & 31 & 31 & 45 & 46 & 41 & 31 & 31 & 31 & 46 & 43 & 41 \\
\hline 46 & 31 & 31 & 31 & 44 & 44 & 38 & 31 & 31 & 31 & 46 & 40 & 38 \\
\hline 47 & 31 & 31 & 31 & 44 & 44 & 37 & 31 & 31 & 31 & 44 & 40 & 37 \\
\hline 49 & 31 & 31 & 31 & 43 & 42 & 36 & 31 & 31 & 31 & 42 & 39 & 36 \\
\hline 50 & 31 & 31 & 31 & 39 & 39 & 35 & 31 & 31 & 31 & 40 & 37 & 35 \\
\hline 51 & 31 & 31 & 31 & 36 & 35 & 34 & 31 & 31 & 31 & 38 & 33 & 34 \\
\hline 52 & 31 & 31 & 31 & 34 & 33 & 33 & 31 & 31 & 31 & 36 & 33 & 33 \\
\hline 53 & 31 & 31 & 31 & 32 & 32 & 31 & 31 & 31 & 31 & 33 & 32 & 31 \\
\hline 54 & 31 & 31 & 31 & 31 & 32 & 31 & 31 & 31 & 31 & 31 & 31 & 31 \\
\hline 55 & 31 & 31 & 31 & 31 & 31 & 31 & 31 & 31 & 31 & 31 & 31 & 31 \\
\hline 56 & 31 & 31 & 31 & 31 & 31 & 31 & 31 & 31 & 31 & 31 & 31 & 31 \\
\hline 57 & 31 & 31 & 31 & 31 & 31 & 31 & 31 & 31 & 31 & 31 & 31 & 31 \\
\hline
\end{tabular}


Table 6 -Time (Days) Vs Temperature $\left({ }^{\circ} \mathrm{C}\right)$ Readings For Teak SD and Rubber SD

\begin{tabular}{|c|c|c|c|c|c|c|c|c|c|c|c|c|}
\hline $\begin{array}{l}\text { Time } \\
\text { Days }\end{array}$ & $\begin{array}{l}\mathrm{T}_{1 \mathrm{~T}} \\
\mathrm{~T}^{0} \mathrm{C}\end{array}$ & $\begin{array}{l}T_{2 T} \\
T^{\circ} \mathrm{C}\end{array}$ & $\begin{array}{l}\mathrm{T}_{3 \mathrm{~T}} \\
\mathrm{~T}^{\circ} \mathrm{C}\end{array}$ & $\begin{array}{l}\mathrm{T}_{4 \mathrm{~T}} \\
\mathrm{~T}^{0} \mathrm{C}\end{array}$ & $\begin{array}{l}\mathrm{T}_{5 \mathrm{~T}} \\
\mathrm{~T}^{\circ} \mathrm{C}\end{array}$ & $\begin{array}{l}\mathrm{T}_{6 \mathrm{~T}} \\
\mathrm{~T}^{\circ} \mathrm{C}\end{array}$ & $\begin{array}{l}\mathrm{T}_{1 \mathrm{R}} \\
\mathrm{T}^{0} \mathrm{C}\end{array}$ & $\begin{array}{l}\mathrm{T}_{2 \mathrm{R}} \\
\mathrm{T}^{0} \mathrm{C}\end{array}$ & $\begin{array}{l}\mathrm{T}_{3 \mathrm{R}} \\
\mathrm{T}^{0} \mathrm{C}\end{array}$ & $\begin{array}{l}\mathrm{T}_{4 \mathrm{R}} \\
\mathrm{T}^{0} \mathrm{C}\end{array}$ & $\begin{array}{l}\mathrm{T}_{5 \mathrm{R}} \\
\mathrm{T}^{0} \mathrm{C}\end{array}$ & $\begin{array}{l}\mathrm{T}_{6 \mathrm{R}} \\
\mathrm{T}^{0} \mathrm{C}\end{array}$ \\
\hline 1 & 28 & 28 & 28 & 28 & 28 & 28 & 28 & 28 & 28 & 28 & 28 & 28 \\
\hline 2 & 28 & 28 & 28 & 33 & 35 & 37 & 28 & 28 & 29 & 36 & 36 & 37 \\
\hline 3 & 28 & 28 & 28 & 40 & 42 & 48 & 28 & 28 & 30 & 42 & 41 & 48 \\
\hline 4 & 28 & 29 & 28 & 42 & 46 & 53 & 28 & 28 & 30 & 43 & 44 & 53 \\
\hline 5 & 28 & 29 & 28 & 42 & 46 & 53 & 29 & 28 & 31 & 44 & 46 & 53 \\
\hline 7 & 29 & 29 & 30 & 43 & 46 & 53 & 29 & 29 & 31 & 45 & 49 & 53 \\
\hline 8 & 29 & 29 & 30 & 43 & 46 & 53 & 29 & 30 & 32 & 46 & 51 & 53 \\
\hline 9 & 29 & 29 & 30 & 44 & 47 & 53 & 29 & 30 & 32 & 47 & 51 & 53 \\
\hline 10 & 29 & 29 & 30 & 44 & 47 & 53 & 29 & 31 & 32 & 49 & 51 & 53 \\
\hline 11 & 29 & 29 & 30 & 44 & 47 & 53 & 30 & 31 & 33 & 51 & 51 & 53 \\
\hline 13 & 29 & 29 & 30 & 47 & 48 & 53 & 30 & 31 & 33 & 51 & 52 & 53 \\
\hline 14 & 29 & 30 & 31 & 47 & 48 & 54 & 30 & 32 & 33 & 51 & 52 & 54 \\
\hline 15 & 29 & 30 & 31 & 47 & 49 & 54 & 30 & 32 & 33 & 51 & 52 & 54 \\
\hline 16 & 29 & 30 & 32 & 47 & 49 & 54 & 30 & 32 & 33 & 52 & 53 & 54 \\
\hline 17 & 31 & 31 & 32 & 47 & 49 & 55 & 32 & 32 & 34 & 52 & 53 & 55 \\
\hline 19 & 31 & 31 & 32 & 47 & 51 & 55 & 32 & 32 & 34 & 52 & 53 & 55 \\
\hline 20 & 31 & 31 & 32 & 47 & 52 & 55 & 32 & 32 & 34 & 52 & 53 & 55 \\
\hline 21 & 31 & 31 & 32 & 48 & 52 & 55 & 32 & 33 & 34 & 52 & 53 & 55 \\
\hline 22 & 31 & 31 & 32 & 48 & 52 & 55 & 32 & 33 & 34 & 53 & 53 & 55 \\
\hline 23 & 31 & 31 & 32 & 48 & 52 & 56 & 32 & 33 & 34 & 53 & 53 & 56 \\
\hline 25 & 31 & 32 & 32 & 48 & 52 & 56 & 33 & 33 & 34 & 53 & 53 & 56 \\
\hline 26 & 31 & 32 & 32 & 48 & 52 & 56 & 33 & 33 & 34 & 53 & 54 & 56 \\
\hline 27 & 31 & 32 & 32 & 48 & 52 & 56 & 33 & 33 & 34 & 53 & 54 & 56 \\
\hline 28 & 31 & 32 & 32 & 48 & 52 & 56 & 33 & 33 & 34 & 53 & 54 & 56 \\
\hline 29 & 31 & 32 & 32 & 48 & 52 & 56 & 33 & 33 & 34 & 53 & 54 & 56 \\
\hline 31 & 32 & 32 & 32 & 48 & 52 & 54 & 33 & 33 & 34 & 53 & 54 & 54 \\
\hline 32 & 32 & 32 & 32 & 48 & 52 & 54 & 33 & 33 & 34 & 53 & 54 & 54 \\
\hline 33 & 32 & 32 & 33 & 48 & 52 & 53 & 33 & 33 & 34 & 53 & 54 & 53 \\
\hline 34 & 32 & 32 & 33 & 48 & 52 & 52 & 33 & 33 & 34 & 53 & 54 & 52 \\
\hline 35 & 32 & 32 & 33 & 48 & 50 & 52 & 33 & 33 & 34 & 53 & 54 & 52 \\
\hline 37 & 32 & 32 & 33 & 48 & 50 & 50 & 32 & 33 & 34 & 53 & 54 & 50 \\
\hline 38 & 31 & 32 & 33 & 48 & 50 & 49 & 32 & 33 & 34 & 53 & 54 & 49 \\
\hline 39 & 31 & 32 & 33 & 48 & 49 & 49 & 32 & 33 & 35 & 52 & 54 & 49 \\
\hline 40 & 31 & 32 & 33 & 48 & 49 & 47 & 32 & 33 & 35 & 52 & 54 & 47 \\
\hline 41 & 31 & 32 & 33 & 48 & 48 & 45 & 32 & 33 & 35 & 52 & 54 & 45 \\
\hline 43 & 31 & 32 & 33 & 47 & 48 & 44 & 32 & 33 & 35 & 50 & 52 & 44 \\
\hline 44 & 31 & 32 & 33 & 47 & 46 & 43 & 32 & 33 & 35 & 48 & 50 & 43 \\
\hline 45 & 31 & 32 & 33 & 45 & 46 & 41 & 32 & 33 & 35 & 46 & 49 & 41 \\
\hline 46 & 31 & 32 & 33 & 44 & 44 & 39 & 32 & 33 & 35 & 44 & 46 & 39 \\
\hline 47 & 31 & 32 & 33 & 44 & 44 & 36 & 32 & 33 & 35 & 42 & 44 & 36 \\
\hline 48 & 31 & 32 & 33 & 43 & 42 & 35 & 32 & 33 & 35 & 42 & 40 & 35 \\
\hline 49 & 31 & 32 & 33 & 39 & 39 & 35 & 32 & 33 & 35 & 40 & 37 & 35 \\
\hline 51 & 31 & 32 & 33 & 36 & 35 & 33 & 32 & 33 & 35 & 38 & 35 & 33 \\
\hline 52 & 31 & 32 & 33 & 34 & 33 & 32 & 32 & 33 & 35 & 36 & 33 & 32 \\
\hline 53 & 31 & 32 & 33 & 32 & 32 & 31 & 32 & 33 & 35 & 32 & 32 & 31 \\
\hline 54 & 31 & 32 & 33 & 31 & 32 & 31 & 32 & 33 & 35 & 32 & 31 & 31 \\
\hline 55 & 31 & 32 & 33 & 31 & 31 & 31 & 32 & 33 & 35 & 31 & 31 & 31 \\
\hline 56 & 31 & 32 & 33 & 31 & 31 & 31 & 32 & 33 & 35 & 31 & 31 & 31 \\
\hline 57 & 31 & 32 & 33 & 31 & 31 & 31 & 32 & 33 & 35 & 31 & 31 & 31 \\
\hline
\end{tabular}



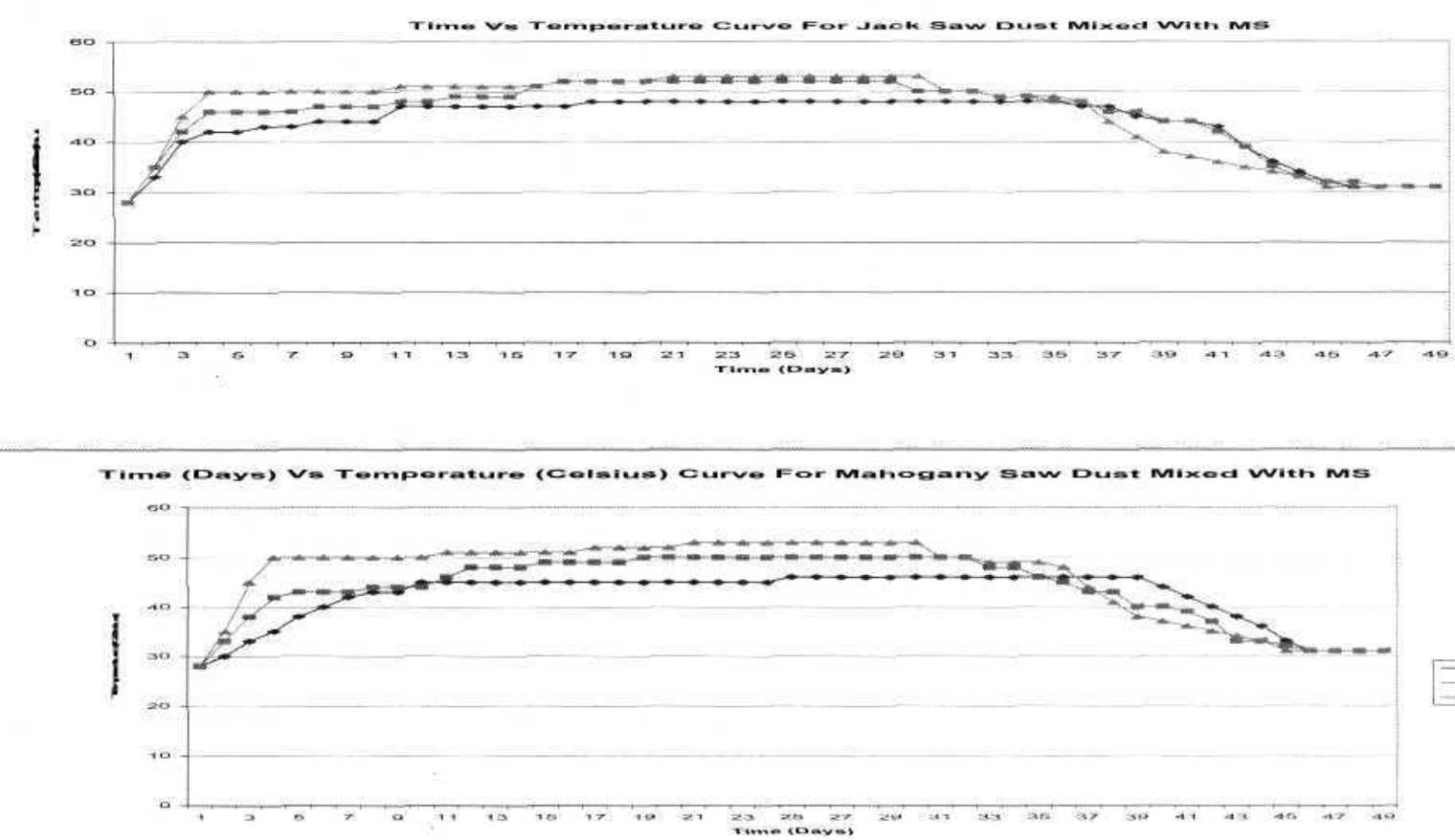

Time Vs Tomperature Curve For Teak Saw Dust Mixed With MS

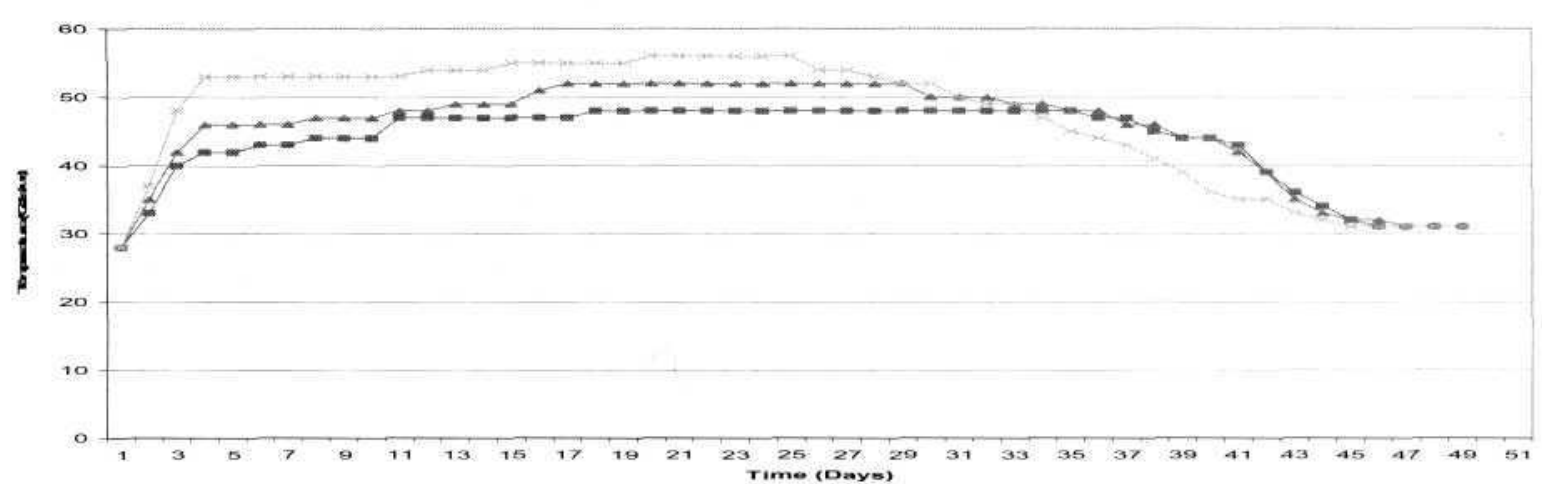

Time Vs Tomperature Graphs For Rubber Saw Dust Mixedl With MS

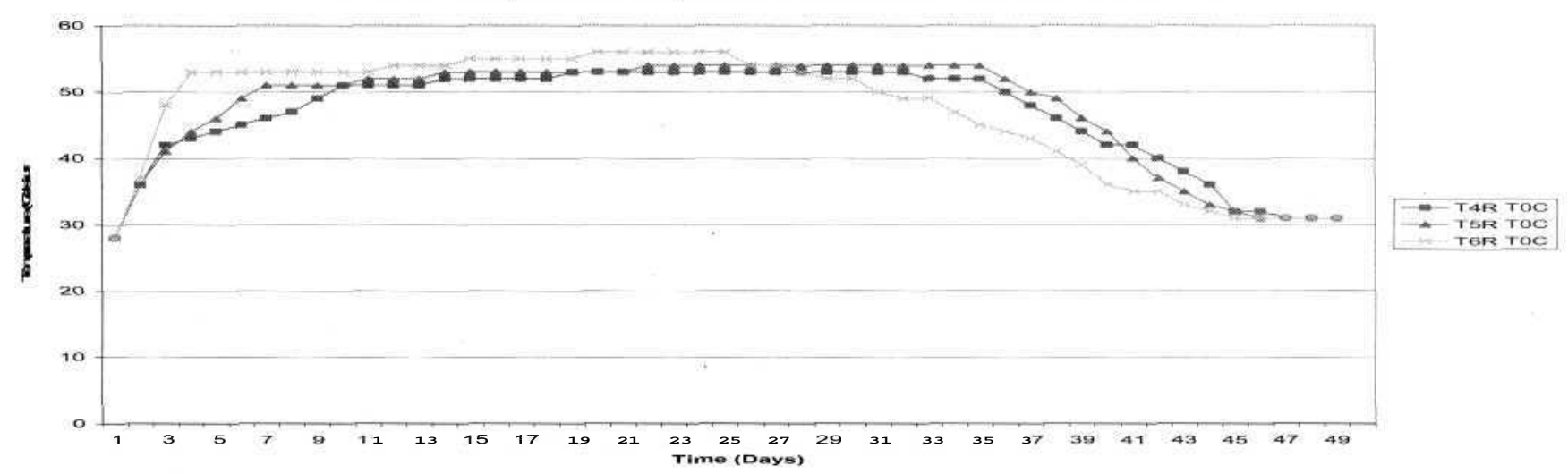




\section{References:}

1. Perera S.A.S, Patented Process For Rapid Digestion Of All Types Of Biomass Into Organic Fertiliser, A Solution To The Urban Solid Waste (USW) And To The Fertiliser Problem In Sri Lanka, The Proceedings of the $22^{\text {nd }}$ International Conference on Solid Waste Technology and Management March 2007, pp. 13121319, (C) Widener University, Philadelphia, USA.

2. Perera S.A.S, Manufacture Of Organic Fertiliser From Vegetable Market Garbage (VMG) Using Eppawela Rock Phosphate And Its' Effects On Rice Cultivation, The Proceedings of the $22^{\text {nd }}$ International Conference on Solid Waste Technology and Management March 2007, pp. 1301-1311 (C) Widener University, Philadelphia, USA.

3. Perera S.A.S, Ratnaweera P., Meegoda J.N., Sustainable Agricultural Practices For Developing Countries, The Proceedings of The First International Conference on Solid and Rock Engineering August 2007, Colombo, Sri Lanka, pp. 1-7, (C) The Geotechnical Society of Sri Lanka.

4. Perera S.A.S, Delta-D Technology, A Technically, Economically And Environmentally Feasible Solution To The Urban Solid Waste (USW) Problem And The Fertiliser Problem In Sri Lanka, Annual Transactions of IESL, pp.129-139, 2007, (C) The Institution of Engineers Sri Lanka.

5. Perera S.A.S, Sustainable Agriculture Through Delta-D Technology, A Solution To Urban Solid Waste And Global Warming, The Proceedings of the $23^{\text {rd }}$ International Conference on Solid Waste Technology and Management March-April 2008, pp. 1403-1413 C Widener University, Philadelphia, USA.

6. Smook Gary A., Handbook For Pulp And Paper Technologies, pp. 1-8, Angus Wilde Publications Inc, Vancouver, Canada, Copyright $@$ by Gary A. Smook

7. Lehninger Albert A., Nelson David L., Cox Michael M., Principles of Biochemistry $\left(2^{\text {nd }}\right.$ Edition), pp. 12-13, 25, 311, 713, Worth Publishers Inc., New York, USA, Copyright (C) 1993, 1982 by Worth Publishers.

8. http://www.mirror.org/ken.roberts/com post.html

9. www.answerbag.com/q

10. weblife.org/humanure/chapter8
11. www.springerlink.com/index/Q1L4Q9L0 OOM53845.pdf

12. www.gardenopus.com/Sawdust.htm

13. vegweb.com/composting/what-not.shtml 